\title{
Tegan Senior
}

REVOLT

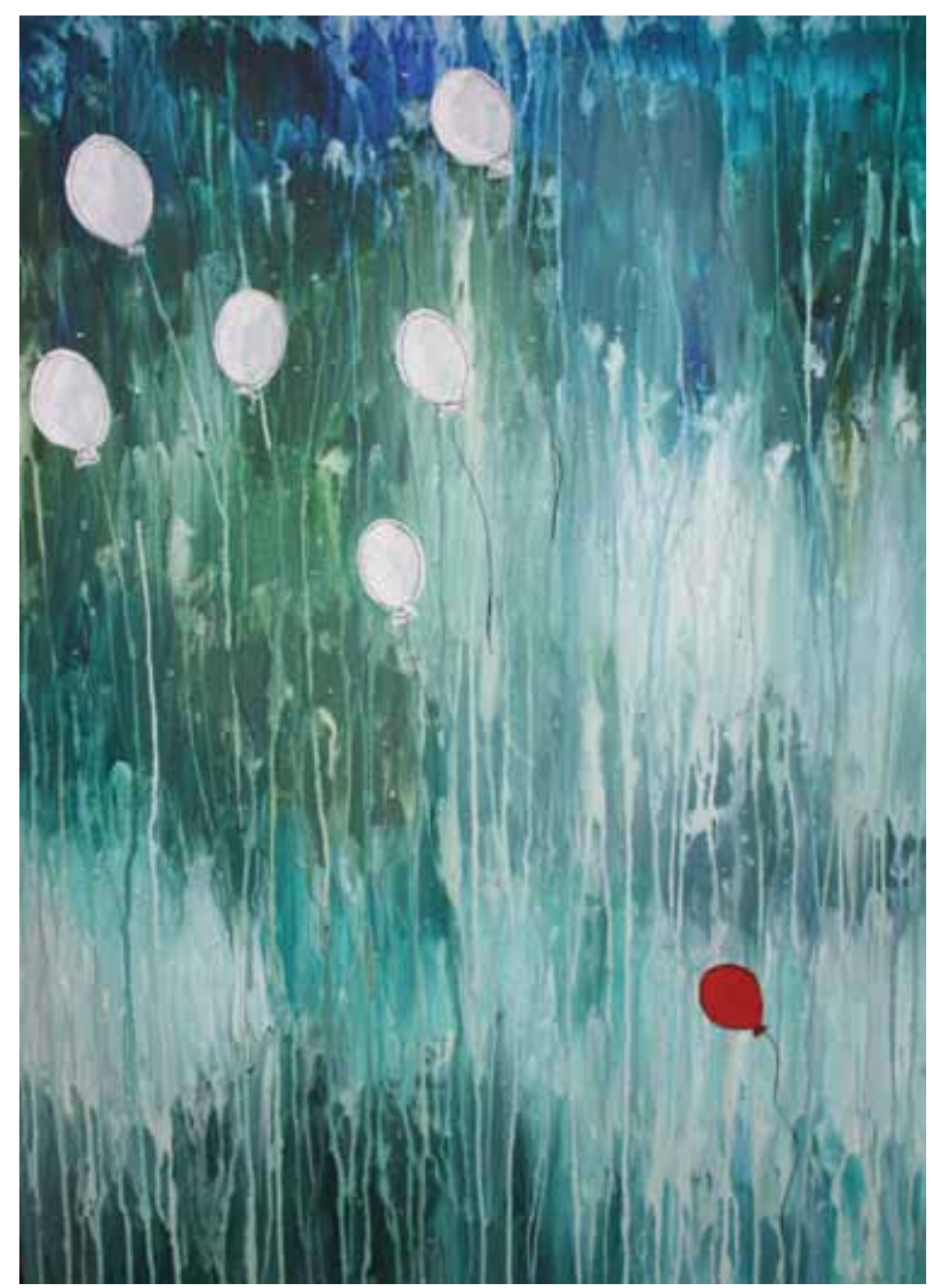

I28 | Offset no. Io 